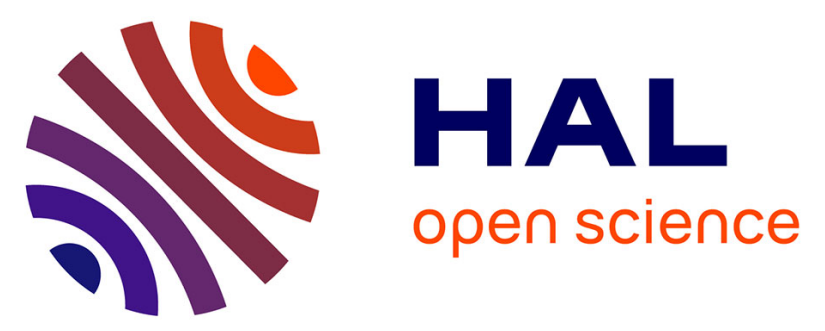

\title{
Reduced phenotypic expression in genetic hemochromatosis with time role of exposure to nongenetic modifiers
}

Yves Deugnier, Jeff Morcet, Fabrice Lainé, Houda Hamdi-Rozé, Anne-Sophie Bollard, Dominique Guyader, Romain Moirand, Edouard Bardou-Jacquet

\section{To cite this version:}

Yves Deugnier, Jeff Morcet, Fabrice Lainé, Houda Hamdi-Rozé, Anne-Sophie Bollard, et al.. Reduced phenotypic expression in genetic hemochromatosis with time role of exposure to nongenetic modifiers. Journal of Hepatology, 2019, 70 (1), pp.118-125. 10.1016/j.jhep.2018.09.009 hal-01903065

\section{HAL Id: hal-01903065}

\section{https://hal-univ-rennes1.archives-ouvertes.fr/hal-01903065}

Submitted on 6 Dec 2018

HAL is a multi-disciplinary open access archive for the deposit and dissemination of scientific research documents, whether they are published or not. The documents may come from teaching and research institutions in France or abroad, or from public or private research centers.
L'archive ouverte pluridisciplinaire HAL, est destinée au dépôt et à la diffusion de documents scientifiques de niveau recherche, publiés ou non, émanant des établissements d'enseignement et de recherche français ou étrangers, des laboratoires publics ou privés. 
Reduced phenotypic expression in genetic hemochromatosis with time: role of exposure to nongenetic modifiers

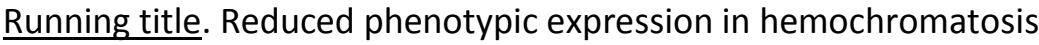

Yves Deugnier $^{1-4}, \mathrm{MD}, \mathrm{PhD}$, Jeff Morcet ${ }^{4}, \mathrm{MD}$, Fabrice Lainé ${ }^{1,4}, \mathrm{MD}$, Houda Hamdi-Roze ${ }^{5}$, Anne-Sophie Bollard $^{1}$, MD, Dominique Guyader ${ }^{1,3}, \mathrm{MD}, \mathrm{PhD}$, Romain Moirand ${ }^{1,3}, \mathrm{MD}, \mathrm{PhD}$, and Edouard BardouJacquet $^{1-3}, \mathrm{MD}, \mathrm{PhD}$.

${ }^{1}$ CHU Rennes, Liver Unit, Pontchaillou Hospital, F-35033 Rennes, France

${ }^{2} \mathrm{CHU}$ Rennes, National reference centre of hemochromatosis and other iron-related disorders, Pontchaillou Hospital, F-35033 Rennes, France

${ }^{3}$ University Rennes 1, Faculty of Medicine, F-35340 Rennes, France

${ }^{4}$ INSERM, CIC 1414, Pontchaillou Hospital, F-35033 Rennes, France

${ }^{5} \mathrm{CHU}$ Rennes, Laboratory of Molecular Genetics, Pontchaillou Hospital, F-35033 Rennes, France

Key words. HFE Hemochromatosis; phenotype; evolution over time; alcohol; tobacco; BMI.

Contact for information. Pr Yves Deugnier, Liver Unit, Pontchaillou University Hospital, 2 rue Henri Le Guilloux, 35033 Rennes cedex, France - Email: yves.deugnier@univ-rennes1.fr - Tel: +33 2992842 97.

List of abbreviations. ALAT: alanine amino transferase, ASAT: aspartate amino transferase, BMI: body mass index, $\mathrm{Cl}$ : confidence interval, F: female, GGT: gammaglutamyl transpeptidase, M: male, MRI: magnetic resonance imaging, MSD: mean standard deviation, SD: standard deviation

Financial support. The LOGIFER database was maintained over time thanks to recurrent public funding (Programme Hospitalier de Recherche Clinique, Agence Nationale de la Recherche, Comité de la Recherche Clinique of Rennes, Société Nationale Française de Gastro-Entérologie) and to the Association Fer et Foie.

Conflict of interest. None of the authors has any conflict of interest to declare in relation to the present study.

Word count. Abstract: 267 - Text: 3617 - Tables: 3 - Figures: 2 
Background. Genetic hemochromatosis is mainly related to the homozygous genotype for the HFE p.Cys282Tyr (C282Y) mutation leading to hepcidin deficiency. Its low penetrance suggests the involvement of cofactors modulating its expression. Aim. To describe the evolution of disease presentation and of non-genetic factors liable to impact hepcidin production in the long term. Patients \& methods. Clinical symptoms, markers of iron load, and risk factors according to the year of diagnosis were recorded over 30 years in a cohort of C282Y homozygotes $\geq 18$ years. Results. 2050 patients [1460 probands (804 males \& 656 females) and 542 relatives (244 males \& 346 females)] were studied. Over time: (i) the proband-to-relative ratio remained roughly stable; (ii) the gender ratio tended towards equilibrium among probands; (iii) age at diagnosis did not change among males and increased among females; (iv) the frequency of diabetes and hepatic fibrosis steadily decreased while that of chronic fatigue and distal joint symptoms remained stable; (v) transferrin saturation, serum ferritin and the amount of iron removed decreased; and (vi) the prevalence of excessive alcohol consumption decreased while that of overweight increased. Tobacco smoking was associated with increased transferrin saturation. Conclusion. Genetic testing did not alter the age at diagnosis, which contrasts with the dramatic decrease in iron load in both genders. Tobacco smoking could be involved in the extent of iron loading. Besides HFE testing, which enables the diagnosis of minor forms of the disease, the reduction of alcohol consumption and the increased frequency of overweight may have played a role in the decrease of iron load in the long term, since these factors are likely to improve hepcidin production.

\section{LAY SUMMARY}

- Genetic hemochromatosis is an inherited disorder secondary to progressive body iron loading. It results in chronic fatigue and in potential liver (cirrhosis), pancreas (diabetes) and joint (arthritis) damage at adulthood.

- The present study showed that tobacco smoking may aggravate iron loading, but that, as a whole, hemochromatosis has became less and less severe over the last 30 years despite older age at diagnosis, likely due to the protective effects of lower alcohol consumption and of increased weight in the French population. 


\section{INTRODUCTION}

In Caucasians, most cases of genetic iron overload result from the homozygous genotype for the HFE p.Cys282Tyr (C282Y) mutation, which leads to impaired production of hepcidin, the key regulator of systemic iron. ${ }^{1}$ This results in increased iron efflux from cells, mainly from enterocytes and macrophages, and consequently in increased serum iron levels and transferrin saturation, leading to abnormal iron deposits in various parenchymas, especially the liver. ${ }^{1}$ The clinical penetrance of the HFE C282Y homozygous genotype is fairly low, estimated at $30 \%$ among males and $1 \%$ among females. ${ }^{2}$ Thus, C282Y homozygosity is a necessary, although not sufficient, condition for developing clinical hemochromatosis. This suggests that genetic and environmental cofactors modulate its expression in terms of both iron load and organ damage. Genetic polymorphisms have been suggested as phenotypic modifiers but none has been found to be frequent enough to explain this low penetrance. ${ }^{3,4}$ This suggests that non-genetic factors are likely to play a key role in disease presentation, especially those liable to interfere with hepcidin production, i.e. alcohol consumption, overweight and tobacco smoking.

The respective roles of the diagnosis bias resulting from the availability of HFE testing from 1997 and of the environmental impact on disease presentation needed to be determined by a large-scale study covering a long period of time before and after 1997. The aim of the present study was thus to describe the evolution of disease presentation over 30 years, taking into account not only the availability of HFE genotyping but also the evolution of exposure to common acquired factors liable to affect hepcidin production in the long term. 


\section{PATIENTS AND METHODS}

\section{Patients}

All C282Y homozygous patients recorded between 1987 and 2016 in the database (LOGIFER) of the Liver Unit in the University Hospital of Rennes, France, with a definite year of diagnosis, untreated and over 18 years at the time of diagnosis, were included in the study.

Data collection was retrospective before 1989 and thereafter prospective. For patients referred before 1997, the diagnosis of C282Y homozygosity was performed retrospectively either on fresh samples obtained during follow-up or on DNA stored at $-80^{\circ} \mathrm{C}$. The diagnosis was prospective from 1997. Data was recorded from patient files by data-managers with double data entry. Quality control was provided by the same clinical research assistant from 1990, and coherence control and statistical analyses were regularly performed by the same bio-statistician (JM) from 2004.

According to French legislation, the LOGIFER survey was notified to the Comité National de I'Informatique et des Libertés (CNIL n 2005/1108633 - Personal privacy authority). Patients were informed of the collection of their personal data in the database and the possibility of opposing it, and they were asked to provide written informed consent at the time of their first contact with the Liver Unit.

\section{Data}

All probands were attending the Liver Unit at the time of diagnosis. Family screening procedures were conducted by the Liver Unit but the referral of relatives to our centre was not the rule, as data was obtained from questionnaires completed by GPs at the time of screening and then handed in together with the consent forms and the material for genetic testing.

The following data collected at the time of diagnosis was extracted from LOGIFER when available:

- Age (years), gender (M/F);

- History of symptoms compatible with hemochromatosis: chronic fatigue, distal / proximal arthralgia, hypogonadism (erectile dysfunction or loss of libido, in males only), cardiomyopathy (arrhythmia or cardiac failure), and diabetes (fasting serum glucose $>1,26$ $\mathrm{g} / \mathrm{l}$ or anti-diabetic therapy);

- History of risk factors: excessive alcohol consumption (males: $>30 \mathrm{~g} / \mathrm{d}$ - females: $>20 \mathrm{~g} / \mathrm{d}$ for more than 5 years) and tobacco smoking (non- or current smoker);

- Weight $(\mathrm{kg})$, height $(\mathrm{cm})$ and body mass index $\left(\mathrm{BMI}-\mathrm{kg} / \mathrm{m}^{2}\right)$; 
- Serum iron, transferrin and ferritin, transferrin saturation, and amount of iron removed calculated from the volume of blood extracted during initial depletion therapy until the achievement of low body iron reserves (serum ferritin $\leq 50 \mu \mathrm{g} / \mathrm{l}$ ), assuming that $500 \mathrm{ml}$ of blood contains $250 \mathrm{mg}$ of elemental iron;

- Liver fibrosis, determined by a liver biopsy using the METAVIR scoring system (F0: no fibrosis to F4: cirrhosis). ${ }^{5}$ In the absence of histological data, patients with serum ferritin $<1000 \mu \mathrm{g} / \mathrm{L}$ were considered to be free from F3-4 fibrosis (= severe fibrosis) according to Guyader et al. ${ }^{6}$ and the others as having missing data. The Guyader score, consisting in the non-invasive prediction of severe fibrosis (range: $0-1$ ), was calculated as previously reported; ${ }^{6}$

- Hepatic symptoms were defined as clinical signs of liver disease (including hepatocellular carcinoma) and/or increased serum transaminase levels and/or hepatic fibrosis on liver biopsy.

\section{Analyses}

Statistical analyses were performed on SAS version 9.4 (SAS Institute, Cary, NC) after dividing the 30year survey into 6 periods of 5 years. A $p$ value $<0.05$ was considered significant.

Comparisons according to periods of time were made using ANOVA for quantitative variables. For qualitative variables, trend significance according to period of time was assessed using the Cochran Armitage test.

Then multivariate analyses adjusted on time periods were run to identify variables independently associated with biochemical iron markers (divided into terciles). Terciles were calculated separately for each gender: transferrin saturation (thresholds: $55 \%$ and $75 \%$ for women, $75 \%$ and $90 \%$ for men), serum ferritin (thresholds: $250 \mu \mathrm{g} / \mathrm{l}$ and $600 \mu \mathrm{g} / \mathrm{l}$ for women, $800 \mu \mathrm{g} / \mathrm{l}$ and $1500 \mu \mathrm{g} / \mathrm{l}$ for men) and amount of iron removed (thresholds: $1.5 \mathrm{~g}$ and $3.5 \mathrm{~g}$ for women, $4.5 \mathrm{~g}$ and $8.5 \mathrm{~g}$ for men). Severe iron overload was defined according to the relevant clinical thresholds: $75 \%$ for transferrin saturation, ${ }^{7,8} 2000 \mu \mathrm{g} / \mathrm{l}$ for serum ferritin, ${ }^{9}$ and $10 \mathrm{~g}$ for the amount of iron removed. ${ }^{4}$ Variables with $p<0.2$ in univariate analyses were introduced into the multivariate models.

To assess whether the associations of iron markers with time periods were independent, Ordinal Logistic Regression models were used to estimate Odds Ratios (OR) with a 95\% confidence interval $(95 \% \mathrm{Cl})$ after verifying the Proportional Odds Assumption. 
A multiple imputation procedure was used for variables with missing data, assuming data to be missing-at-random. Missing data was filled in 200 times to generate 200 complete data sets using the MI procedure on SAS 9.4 to handle missing values for the covariates. Gender, age at diagnosis, year of diagnosis, year of birth, proband/relative status, excessive alcohol intake, tobacco smoking, blood pressure, BMI, chronic fatigue, diabetes, heart, liver and joint symptoms, hypogonadism, hepatic fibrosis, serum iron, serum ferritin, serum transferrin, transferrin saturation, ASAT, ALAT, GGT, mean corpuscular volume, HDL cholesterol, triglycerides, fasting glycaemia, amount of iron removed and hepatic iron content on MRI were introduced into the MI procedure. The 200 complete data sets were then analysed using an ordinal logistic regression procedure, and the results from these datasets were combined for the imputation study using the MIANALYZE procedure on SAS 9.4 with Rubin's rule. Results were expressed as OR with a $95 \% \mathrm{Cl}$. Ordinal logistic regressions were also conducted on data without imputation. The results were similar (data not shown).

The results are presented as mean (SD) in the tables and mean (MSD) in the figures or as $n$ (\% - 95\% confidence interval) in both tables and figures.

\section{RESULTS}

\section{Demographic data}

At the time of the study, LOGIFER comprised 11884 individuals, 2258 of whom were C282Y homozygotes. Among these patients, 208 were not eligible because of uncertainty about the date of diagnosis $(n=20)$, diagnosis before 1987 and/or phlebotomy therapy before the record in LOGIFER $(n=135)$, or age younger than 18 years $(n=53)$. The study was thus conducted on 2050 individuals (1048 males and 1002 females), 1460 of whom were probands (804 males and 656 females) and 590 were relatives (244 males and 346 females). The recruitment increased to reach 17 to 95 homozygotes per year from 1987 to 1992, reached a plateau between 1993 and 2008 (median 88 range 70-132) and then slowly decreased to fewer than 50 . The median number of patients per year was 70 (range: 17-132) and the median number of patients per period was 369 (range: 179-446). Before 1997, most probands were males. Thereafter, the gender ratio among probands decreased, tending towards a balance (Table 1). The proband-to-relative ratio was 1.5 to 2.9 higher for men than for women, but with no significant difference according to the period of time (Table 1).

\section{Age at diagnosis}

At diagnosis, the males were younger than the females ( $44 \pm 13$ versus $47 \pm 14-p<0.0001$ ). The probands were older (all: $46.3 \pm 13.4$ - males: $44.7 \pm 11.9$ - females: $47.9 \pm 14.6$ ) than the relatives 
(all: $43.7 \pm 13.4$ - males: $41.5 \pm 13.2$ - females: $45.2 \pm 13.4$ ), these differences being significant $(p<0.0001, p=0.0001$ and $p=0.004$ respectively). Age at diagnosis did not vary with time among males, and increased significantly among females (Table 2).

\section{Early symptoms}

The circumstances of diagnosis varied over time but with no particular tendency. Systematic biochemical assessments. family screening, clinical symptoms compatible with iron excess and clinical symptoms unrelated to iron excess led to the diagnosis of hemochromatosis in respectively 30.3\% (95\%Cl: $28.3-32.4), 30.1 \%$ (95\%Cl: $28.0-32.1), 29.1 \%$ (95\%Cl: $21.1-31.1)$ and $10.5 \%$ (95\%Cl: $9.1-$ 11.8) of cases among the 1960 subjects for whom the information was available. Chronic fatigue and arthralgia were the most common initial iron-related symptoms. Their frequency did not vary significantly with time.

\section{Clinical expression}

The most frequent symptom was chronic fatigue, present for 32 to $47 \%$ of males and for 26 to $43 \%$ of females according to time period (variations not significant). The frequency of distal arthralgia remained stable within the range of $25-33 \%$ among males and $27-30 \%$ among females through the [02-06] period and then decreased to $17 \%$ among males (95\% Cl: $9.4-23.9)$ and $25 \%$ among females (95\% Cl: $16.5-34.0)$ in the last period. Proximal arthralgia was present in 10 to $15 \%$ of patients of both genders with no significant variation according to period of time. Between the first and the last period, the frequency of hepatic symptoms significantly decreased from 33.0 to $17.5 \%$ among males (95\% Cl: $24.3-41.7$ and 10.8-24.1 respectively) and from 16.4 to $0.8 \%$ among females $(95 \% \mathrm{Cl}: 7.5-25.3$ and 0-2.5 respectively). The same was found for severe fibrosis and diabetes (Table 2 and figure 2). Similarly, the number of cases of hepatocellular carcinoma detected at the time of diagnosis decreased across the six periods $(3.8 \%, 2.7 \%, 1.1 \%, 0.8 \%, 1.5 \%$ and $0.3 \%$ respectively). Cardiac symptoms and hypogonadism were rare (5.4 and 5.2\% respectively, in the whole population), making it impossible to study their evolution over time.

\section{Markers of iron excess and overall iron load}

All markers of iron excess decreased over time (Table 2 and figure 1). Transferrin saturation decreased in both genders, but the decrease began before 1997 and was linear and more marked among females. Serum ferritin levels dropped in the [97-01] period and then remained globally stable in both genders. The amount of iron removed decreased more regularly over time in males than in females, and the reduction began before 1997. 
The number of cases with indicators of severe iron overload (transferrin saturation $\geq 75 \%$ or serum ferritin $\geq 2000 \mu \mathrm{g} / \mathrm{l}$ or iron removed $\geq 10 \mathrm{~g}$ ) significantly decreased with time among both males and females (Figure 1). Severe fibrosis was found in liver biopsies for $44 \%$ of patients with transferrin saturation $\geq 75 \%, 90.5 \%$ of patients with serum ferritin $\geq 2000 \mu \mathrm{g} / \mathrm{l}$ and $93.8 \%$ of patients with iron removed $\geq 10 \mathrm{~g}$ compared to $12.1 \%, 7.2 \%$ and $8.5 \%$ among patients with transferrin saturation < $75 \%$, serum ferritin $<2000 \mu \mathrm{g} / \mathrm{l}$ and iron removed $<10 \mathrm{~g}$ respectively. Only $7 \%$ of the patients with transferrin saturation $\geq 75 \%$ had normal serum ferritin levels. None had severe fibrosis.

\section{Alcohol, tobacco and body mass index}

The frequency of excessive alcohol consumption dropped dramatically in the 3 early periods among males and then reached a plateau (Table 2 and figure 2). It remained low with a decreasing but nonsignificant trend among females. Tobacco use did not vary significantly with time (Table 2). Body mass index increased over time, significantly among males and exhibiting a trend among females (Table 2 and figure 2). The proportion of individuals with a body mass index exceeding $30 \mathrm{~kg} / \mathrm{m}^{2}$ increased non-significantly among males $(p=0.06)$ and significantly among females $(p=0.006)$.

\section{$\underline{\text { Multivariate analyses }}$}

Multivariate analyses were run to look for factors independently associated with markers of iron excess (i.e. transferrin saturation, serum ferritin and amount of iron removed) after adjustment on period of time, in order to systematically take the availability of HFE testing into account. Because the results differed according to gender in univariate analyses, males and females were studied separately. As indicated in table 3 and figure 1, the decrease in markers of iron excess began before the [97-01] period and continued thereafter for transferrin saturation in both genders and for the amount of iron removed among males. Older age at diagnosis and proband status were associated with an increase in all markers, but the age threshold differed between males ( $\geq 35$ years) and females ( $\geq 50$ years). Body mass index had an opposite effect on transferrin saturation (decrease among females) and serum ferritin (increase among males). Excessive alcohol intake was associated with increased transferrin saturation among females, increased ferritin levels in both genders, and increased amounts of iron removed among males only. Tobacco smoking was independently associated with increased transferrin saturation in both genders. 


\section{DISCUSSION}

The present study confirmed that the phenotypic expression of C282Y homozygosity has progressively changed over the last 30 years with a re-balancing of the gender ratio among probands and reduced severity for both genders, despite older age at diagnosis, at least among females. This was associated not only with the early implementation of family screening procedures and subsequently with the availability of HFE testing, but also with the gradual increase in the frequency of factors known to enhance hepcidin production, i.e. the reduction in alcohol consumption and overweight. Finally, this study has shown that tobacco smoking was independently associated with increased transferrin saturation, which suggests that tobacco is a putative aggravating factor for iron overload in the long term.

The impact of the availability of HFE typing on disease presentation at the time of diagnosis was previously assessed in 3 French, ${ }^{10}$ German, ${ }^{11}$ and Italian ${ }^{12}$ studies, all indicating that patients diagnosed after 1996 were less symptomatic and older at the time of diagnosis. The patient samples were small ( $n=415,269$ and 414 respectively) precluding relevant subgroup analyses in long surveys of 23,30 and 40 year duration respectively. The Italian study ${ }^{12}$ was the only one to analyse the impact of acquired factors on disease expression, but it studied a heterogeneous group of 269 C282Y homozygotes and 69 compound heterozygotes who were later shown to be quite different with regard to cofactors of morbidity. ${ }^{13}$ In addition, only 30 patients in this composite group had been diagnosed before 1997, compromising the results of comparisons before/after the implementation of HFE testing.

The strengths of the present study were the long period of time covered (30 years), the large number of patients $(>2000)$ enabling analyses of subgroups according to period of time, gender and proband/relative status, the homogeneity and the prospective collection of data, and the thoroughness of the quality insurance process with standardization of biochemical data as early as 1989, a double entry process and regular coherence tests. Its main weakness was the amount of missing clinical data, especially with respect to body mass index, excessive alcohol consumption and tobacco smoking (Table 2). However, their frequency did not exceed $30 \%$ and did not vary significantly according to period of time, which enabled the running of imputation procedures. In addition, the results were similar with or without imputation procedures (data not shown). Periods of time of 5-year duration were chosen in order to obtain 2 periods before the availability of HFE testing, one period starting in 1997, when HFE testing was routinely made available, and samples of sufficient size to enable separate analyses among males and females. 
The present findings confirmed that the availability of HFE testing has resulted in alterations in disease presentation. The proband-to-relative ratio remained roughly stable in both genders over time, but it was significantly higher among males (Table 1). The gender ratio decreased among both probands and relatives, with a clear cut-off in 1997. This resulted in a gender balance among probands and in lasting female predominance among relatives over recent years, which is not surprising since females are much more responsive to family screening procedures. ${ }^{14}$ This female bias was already found by Scotet et al ${ }^{10}$ when comparing the presentation of HFE hemochromatosis in 415 C282Y homozygotes before and after 1996. In fact, the present data clearly indicates that before the 1997 cut-off the gender ratio was already decreasing. This was probably related to the awareness of both GPs and patients - especially females - towards hemochromatosis in an area with high disease prevalence and the implementation of HLA-based family screening policy in the 1980s. ${ }^{15}$ The availability of genetic testing probably resulted in an amplification of the trend by enabling the diagnosis of less severe cases mainly affecting females. ${ }^{10-12}$

The present study demonstrated that iron-related organ damage has become less and less severe over time. The prevalence of diabetes steadily decreased between 1987 and 2016 among males, halving despite the progressive increase in body mass index. It remained low with a non-significant decrease among females. The decrease in the frequency of severe hepatic fibrosis began before the availability of HFE testing and followed the same curve in both genders. Our findings indicate that this was not due to earlier diagnosis by genotyping unlike what has been suggested previously. ${ }^{10,11}$ Because indications for liver biopsy were changed - and progressively restricted - in the time period covered by the study, 6 this should be interpreted with caution. However, the Guyader score predicting severe fibrosis decreased over time, which makes a bias related to changes in biopsy indications unlikely. Otherwise, it is interesting to note that the evolution of liver fibrosis and that of alcohol consumption ran parallel, with a slight rebound in recent years. This is in line with previous studies showing that alcohol is a major factor in disease severity. ${ }^{16,17}$ Over the last thirty years, the frequency of distal joint symptoms, a key feature of hemochromatosis not fully correlated with the level of iron load, ${ }^{18}$ did not significantly decrease and remained higher than that of diabetes and hepatic fibrosis. The present data illustrates that hemochromatosis is shifting from a metabolic and hepatic disease to a rheumatologic disease.

Several criteria associated with severe iron overload were studied in the present study: transferrin saturation exceeding $75 \%$, shown to be associated with increased labile plasma iron, the most toxic form of iron, ${ }^{7}$ serum ferritin levels greater than $2000 \mu \mathrm{g} / \mathrm{l}$ reported to be associated with reduced survival among C282Y homozygous patients, ${ }^{9}$ and amount of iron removed greater than $10 \mathrm{~g}$ which corresponds to marked iron excess. ${ }^{4}$ All were less and less frequent as time went by, among females 
as well as males, and among probands as well as relatives, which demonstrates that iron overload has genuinely decreased among French patients over the last thirty years.

In the present series, alongside the reduction in iron load, alcohol consumption decreased and body weight increased, mainly among males who had stronger evidence of decreased phenotypic expression than did females. Alcohol was demonstrated to inhibit hepcidin production ${ }^{19}$ making it likely to increase iron overload in the long term. Conversely, more and more data is accumulating demonstrating extrahepatic hepcidin production, mainly by visceral adipose tissue ${ }^{20}$ and by the pancreas, alongside insulin synthesis. ${ }^{21}$ Indeed, serum hepcidin levels were significantly higher among overweight females than among lean $\mathrm{C} 282 \mathrm{Y}$ homozygous females. ${ }^{22}$ These findings suggest that both the decreased frequency of excessive alcohol intake and the increased frequency of overweight over time may have contributed to the partial correction of hepcidin deficiency, and thus to reducing iron load. Paradoxically, serum ferritin levels, which had dramatically dropped in the [9701] period, remained stable while the amount of iron removed continued to decrease. This dissociation between the two iron markers could be explained by the increase in body mass index, since serum ferritin levels tend to overestimate iron excess in overweight patients compared to C282Y homozygotes. ${ }^{22,23}$

Tobacco smoking, another risk factor, was found to be independently associated with increased transferrin saturation. This is not surprising, since it has been shown to induce chronic hypoxia, which inhibits hepcidin production. ${ }^{24}$ It could be hypothesized that tobacco use leads to an aggravation of iron overload by increasing the levels of non-transferrin-bound iron, the form of iron involved in the setting of parenchymal iron loading. ${ }^{25}$ Finally, other environmental factors not taken into account in the present study nor in previous studies may have contributed to reducing the severity of hemochromatosis, especially changes in diet. Iron excess is mainly related to heme intake, i.e. to red meat consumption. In France, beef consumption regularly increased from 28 to 32 $\mathrm{Kg} /$ inhabitant/year between 1960 to 1980, and has thereafter been steadily decreasing to reach 24 Kg/inhabitant/year in 2014 (http://www.credoc.fr).

Surprisingly, age at diagnosis not only did not decrease with time, but on the contrary, increased significantly among females and exhibiting a trend among males. This was also noted by Scotet et al. ${ }^{10}$ and by Triess et al. ${ }^{11}$ Several explanations could be suggested for this intriguing fact. First, the mean age at diagnosis is between 40 and 50 years, corresponding to the age at which systematic biochemical investigations are commonly offered to patients. Second, the decrease in iron load over time is partially unrelated to the availability of HFE testing, as demonstrated here, resulting in 
delaying the moment of diagnosis. Third, there is an absence of correlation between iron burden and age over 40 years, as previously reported by Adams et al. ${ }^{26}$

\section{CONCLUSION}

This large overview of hemochromatosis over 30 years confirms the dramatic decrease in iron load in terms of both iron excess and liver and pancreas damage. It shows that hemochromatosis is becoming a rheumatologic disease, and suggests that tobacco smoking could aggravate iron overload, possibly by an aggravation of hepcidin deficiency. Finally, it indicates that, besides the implementation of HFE testing, which has enabled the diagnosis of minor forms of the disease, the reduction in alcohol consumption and the increased frequency of overweight may have played a role in the decrease of iron overload in the long term, probably as a result of the improvement in hepcidin production.

Acknowledgments. The authors would like to thank all medical doctors from the Liver Unit in Rennes for allowing them to include their patients in the present study, the nursing staff for the daily care of the patients, Michèle Perrin for keeping track of patient records and maintaining the database, Béatrice Leclerc for managing the administration and organizing family screening procedures, and Stuart Byrom (Direction de la Recherche et de I'Innovation, CHU de Rennes) for reviewing the English version of the manuscript. 


\section{REFERENCES}

1. Powell LW, Seckington RC, Deugnier Y. Hemochromatosis. Lancet 2016; 388(10045): 706-16.

2. Allen KJ, Gurrin LC, Constantine CC, et al. Iron-overload-related disease in HFE hereditary hemochromatosis. The New England journal of medicine 2008; 358(3): 221-30.

3. de Tayrac M, Roth MP, Jouanolle AM, et al. Genome-wide association study identifies TF as a significant modifier gene of iron metabolism in HFE hemochromatosis. J Hepatol 2015; 62(3): 664-72.

4. McLaren CE, Emond MJ, Subramaniam VN, et al. Exome sequencing in HFE C282Y homozygous men with extreme phenotypes identifies a GNPAT variant associated with severe iron overload. Hepatology 2015.

5. Bedossa P, Poynard T. An algorithm for the grading of activity in chronic hepatitis C. The METAVIR Cooperative Study Group. Hepatology 1996; 24(2): 289-93.

6. Guyader D, Jacquelinet C, Moirand R, et al. Noninvasive prediction of fibrosis in C282Y homozygous hemochromatosis. Gastroenterology 1998; 115(4): 929-36.

7. Le Lan C, Loreal O, Cohen T, et al. Redox active plasma iron in C282Y/C282Y hemochromatosis. Blood 2005; 105(11): 4527-31.

8. Gurrin LC, Osborne NJ, Constantine CC, et al. The natural history of serum iron indices for HFE C282Y homozygosity associated with hereditary hemochromatosis. Gastroenterology 2008; 135(6): 1945-52.

9. Bardou-Jacquet E, Morcet J, Manet G, et al. Decreased Cardiovascular and Extrahepatic Cancer-Related Mortality In Treated Patients with Mild HFE Hemochromatosis. J Hepatol 2014.

10. Scotet V, Le Gac G, Merour MC, et al. Impact of HFE genetic testing on clinical presentation of hereditary hemochromatosis: new epidemiological data. BMC Med Genet 2005; 6: 24.

11. Triess C, von Figura G, Stuhrmann M, et al. Diagnosis of hereditary hemochromatosis in the era of genetic testing. Dig Dis Sci 2012; 57(11): 2988-94.

12. Fracanzani AL, Piperno A, Valenti L, et al. Hemochromatosis in Italy in the last $\mathbf{3 0}$ years: role of genetic and acquired factors. Hepatology 2010; 51(2): 501-10.

13. Gurrin LC, Bertalli NA, Dalton GW, et al. HFE C282Y/H63D compound heterozygotes are at low risk of hemochromatosis-related morbidity. Hepatology 2009; 50(1): 94-101.

14. Force USPST. Screening for hemochromatosis: recommendation statement. Ann Intern Med 2006; 145(3): 204-8. 
15. Simon M, Bourel M, Genetet B, Fauchet R. Idiopathic hemochromatosis. Demonstration of recessive transmission and early detection by family HLA typing. The New England journal of medicine 1977; 297(19): 1017-21.

16. Fletcher LM, Dixon JL, Purdie DM, Powell LW, Crawford DH. Excess alcohol greatly increases the prevalence of cirrhosis in hereditary hemochromatosis. Gastroenterology 2002; 122(2): 281-9.

17. Loreal O, Deugnier Y, Moirand R, et al. Liver fibrosis in genetic hemochromatosis. Respective roles of iron and non-iron-related factors in 127 homozygous patients. J Hepatol 1992; 16(1-2): 1227.

18. Guggenbuhl $\mathrm{P}$, Brissot $\mathrm{P}$, Loreal $\mathrm{O}$. Miscellaneous non-inflammatory musculoskeletal conditions. Hemochromatosis: the bone and the joint. Best Pract Res Clin Rheumatol 2011; 25(5): 649-64.

19. Harrison-Findik DD, Klein E, Crist C, Evans J, Timchenko N, Gollan J. Iron-mediated regulation of liver hepcidin expression in rats and mice is abolished by alcohol. Hepatology 2007; 46(6): 197985.

20. Bekri S, Gual P, Anty R, et al. Increased adipose tissue expression of hepcidin in severe obesity is independent from diabetes and NASH. Gastroenterology 2006; 131(3): 788-96.

21. Hansen JB, Moen IW, Mandrup-Poulsen T. Iron: the hard player in diabetes pathophysiology. Acta Physiol (Oxf) 2014; 210(4): 717-32.

22. Desgrippes R, Laine F, Morcet J, et al. Decreased iron burden in overweight C282Y homozygous women: Putative role of increased hepcidin production. Hepatology 2013; 57(5): 178492.

23. Guillygomarc'h A, Mendler MH, Moirand R, et al. Venesection therapy of insulin resistanceassociated hepatic iron overload. J Hepatol 2001; 35(3): 344-9.

24. Peyssonnaux C, Zinkernagel AS, Schuepbach RA, et al. Regulation of iron homeostasis by the hypoxia-inducible transcription factors (HIFs). J Clin Invest 2007; 117(7): 1926-32.

25. Brissot P, Ropert M, Le Lan C, Loreal O. Non-transferrin bound iron: a key role in iron overload and iron toxicity. Biochim Biophys Acta 2012; 1820(3): 403-10.

26. Adams PC, Deugnier Y, Moirand R, Brissot P. The relationship between iron overload, clinical symptoms, and age in 410 patients with genetic hemochromatosis. Hepatology 1997; 25(1): 162-6.

\section{Legends of tables}




\section{Table 1}

Gender ratio and proband-to-relative ratio according to time period.

\section{Table 2}

Evolution of markers of iron overload, organ damage and risk factors according to time period and to gender among $2050 \mathrm{C} 282 \mathrm{Y}$ homozygotes. ANOVA for continuous variables and the Cochrane Armitage test for categorical variables.

\section{Table 3}

Results of multivariate analyses with adjustment on time period. All variables significantly associated with the variables to be explained (transferrin saturation, serum ferritin and amount of iron removed) were introduced into the models when $p<0.2$ in univariate analysis. Results expressed as odds ratio [95\% confidence interval]

\section{Figure legends}

\section{Figure 1}

Evolution of markers of iron excess and severe iron overload according to time period and gender. Severe iron overload was defined as transferrin saturation $\geq 75 \%$ or serum ferritin $\geq$ $2000 \mu \mathrm{g} / \mathrm{l}$ or amount of iron removed $\geq 10 \mathrm{~g}$. Results are expressed as mean (MSD) or \% $(95 \% \mathrm{Cl})$ as appropriate. Statistics: ANOVA and the Cochrane Armitage test as appropriate.

\section{Figure 2}

Evolution of body mass index and of the prevalence of diabetes, excessive alcohol consumption and severe liver fibrosis according to time period and to gender. Results expressed as mean (MSD) or $\%(95 \% \mathrm{Cl})$ as appropriate. Statistics: ANOVA and the Cochrane Armitage test as appropriate. 
Table 1

Years

$[87-91] \quad[92-96] \quad[97-01] \quad[02-06] \quad[07-11] \quad[12-16]$

$(n=179) \quad(n=444) \quad(n=440) \quad(n=446) \quad(n=297) \quad(n=244) \quad \mathrm{p}^{*}$

Sex ratio (M/F)

$\begin{array}{llllllll}\text { All } & 1.67 & 1.44 & 0.91 & 0.83 & 0.84 & 1.07 & 0.32\end{array}$

$\begin{array}{llllllll}\text { Probands } & 2.16 & 1.80 & 1.01 & 0.98 & 0.97 & 1.18 & 0.88\end{array}$

$\begin{array}{llllllll}\text { Relatives } & 0.74 & 0.92 & 0.70 & 0.60 & 0.58 & 0.72 & 0.08\end{array}$

\section{Proband to relative ratio}

$\begin{array}{rrrrrrrr}\text { All } & 3.48 & 2.13 & 2.76 & 1.84 & 2.54 & 3.88 & 0.39 \\ \text { Males } & 5.59 & 2.85 & 3.38 & 2.42 & 3.39 & 5.00 & 0.88 \\ \text { Females } & 1.91 & 1.46 & 2.33 & 1.49 & 2.04 & 3.07 & 0.08\end{array}$

* Test of Cochrane Armitage 
Table 2

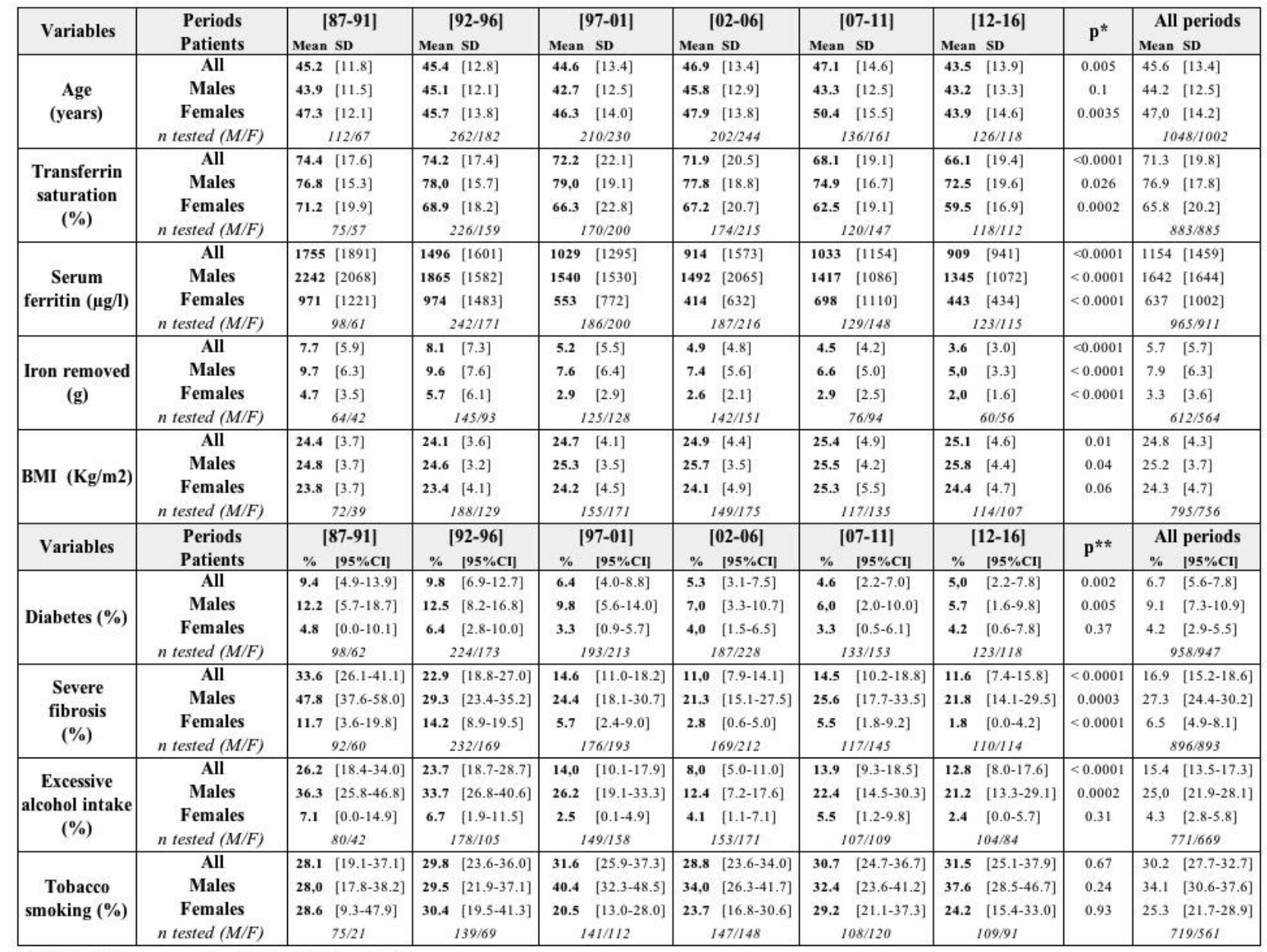

*ANOVA with Levene correction - ** Test of Cochrane Armitage - 
Table 3

\begin{tabular}{|c|c|c|c|c|c|c|c|c|}
\hline & \multicolumn{2}{|c|}{ Transferrin saturation } & \multicolumn{2}{|c|}{ Serum ferritin } & \multicolumn{2}{|c|}{ Amount of iron removed } & \multicolumn{2}{|c|}{ Severe iron burden } \\
\hline & Males & Females & Males & Females & Males & Females & Males & Females \\
\hline \multicolumn{9}{|l|}{ Year of diagnosis } \\
\hline [87-91] & $1.59[0.94-2.70]$ & $3.43[1.87-6.32]$ & $1.77[1.04-3.00]$ & $2.58[1.40-4.74]$ & $4.11[2.27-7.43]$ & $4.00[1.97-8.12]$ & $2.47[1.30-4.68]$ & $4.69[2.31-9.51]$ \\
\hline [92-96] & $1.66[1.09-2.52]$ & $2.66[1.68-4.22]$ & $1.56[1.01-2.40]$ & $1.99[1.26-3.16]$ & $2.83[1.74-4.60]$ & $2.98[1.69-5.25]$ & $2.51[1.53-4.13]$ & $4.12[2.33-7.27]$ \\
\hline [97-01] & $1.85[1.18-2.89]$ & $2.14[1.38-3.32]$ & $1.14[0.73-1.77]$ & $1.01[0.65-1.56]$ & $1.84[1.10-3.09]$ & $1.77[1.06-2.96]$ & $1.78[1.07-2.95]$ & $3.40[1.95-5.91]$ \\
\hline$[02-06]$ & $1.55[1.00-2.40]$ & $2.31[1.50-3.57]$ & $0.89[0.57-1.38]$ & $0.75[0.48-1.16]$ & $1.51[0.92-2.46]$ & $1.44[0.87-2.37]$ & $1.43[0.87-2.35]$ & $3.28[1.89-5.68]$ \\
\hline [07-11] & $0.96[0.60-1.56]$ & $1.50[0.95-2.38]$ & $1.06[0.66-1.71]$ & $1.18[0.74-1.90]$ & $1.57[0.91-2.73]$ & $1.55[0.90-2.67]$ & $1.08[0.63-1.83]$ & $1.58[0.87-2.87]$ \\
\hline$[12-16]$ & 1 & 1 & 1 & 1 & 1 & 1 & 1 & 1 \\
\hline \multicolumn{9}{|l|}{ Age at diagnosis } \\
\hline $18-34$ & 1 & $0.67[0.47-0.95]$ & 1 & $0.32[0.22-0.45]$ & 1 & $0.47[0.32-0.69]$ & 1 & \\
\hline $35-49$ & $1.49[1.09-2.03]$ & $0.69[0.52-0.92]$ & $2.88[2.09-3.97]$ & $0.32[0.24-0.43]$ & $2.28[1.62-3.22]$ & $0.66[0.47-0.93]$ & $1.69[1.18-2.42]$ & \\
\hline 250 & $1.44[1.02-2.03]$ & 1 & $3.52[2.44-5.07]$ & 1 & $2.95[2.00-4.36]$ & 1 & $1.87[1.26-2.78]$ & \\
\hline \multicolumn{9}{|l|}{ Proband status } \\
\hline No & 1 & 1 & 1 & 1 & 1 & 1 & 1 & 1 \\
\hline Yes & $1.48[1.10-2.00]$ & $1.61[1.24-2.09]$ & $2.14[1.57-2.93]$ & $2.98[2.26-3.92]$ & $1.72[1.21-2.47]$ & $1.56[1.13-2.15]$ & $1.74[1.23-2.45]$ & $1.63[1.21-2.21]$ \\
\hline \multicolumn{9}{|l|}{ Tobacco smoking } \\
\hline No & 1 & 1 & & & & & 1 & 1 \\
\hline Yes & $1.49[1.11-2.00]$ & $1.79[1.23-2.62]$ & & & & & $1.65[1.14-2.40]$ & $1.67[1.11-2.51]$ \\
\hline \multicolumn{9}{|l|}{ Body mass index } \\
\hline$<25$ & & 1 & 1 & & & & & \\
\hline $25-30$ & & $0.80[0.58-1.09]$ & $1.12[0.84-1.48]$ & & & & & \\
\hline 230 & & $0.61[0.38-0.96]$ & $1.61[1.00-2.60]$ & & & & & \\
\hline \multicolumn{9}{|c|}{ Excessve alcohol intake } \\
\hline No & & 1 & 1 & 1 & 1 & & & 1 \\
\hline Yes & & $2.86[1.13-7.27]$ & $1.51[1.08-2.12]$ & $1.98[1.20-3.27]$ & $1.45[1.00-2.10]$ & & & $3.12[1.20-8.11]$ \\
\hline \multicolumn{9}{|l|}{ Diabetes } \\
\hline No & & & 1 & & 1 & 1 & & \\
\hline Yes & & & $2.51[1.70-3.71]$ & & $2.23[1.50-3.32]$ & $1.64[1.04-2.59]$ & & \\
\hline
\end{tabular}




\section{Figure 1}
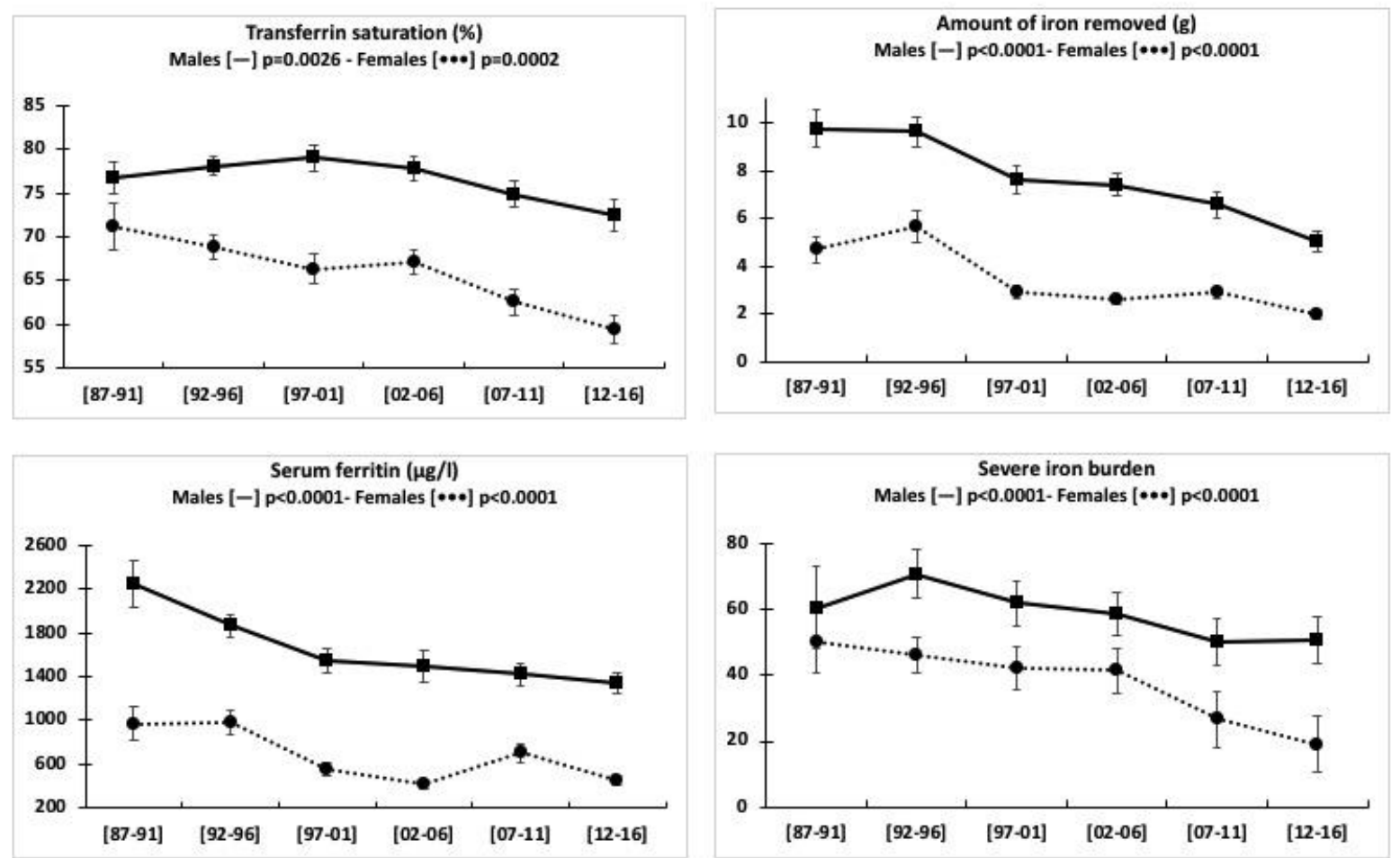


\section{Figure 2}
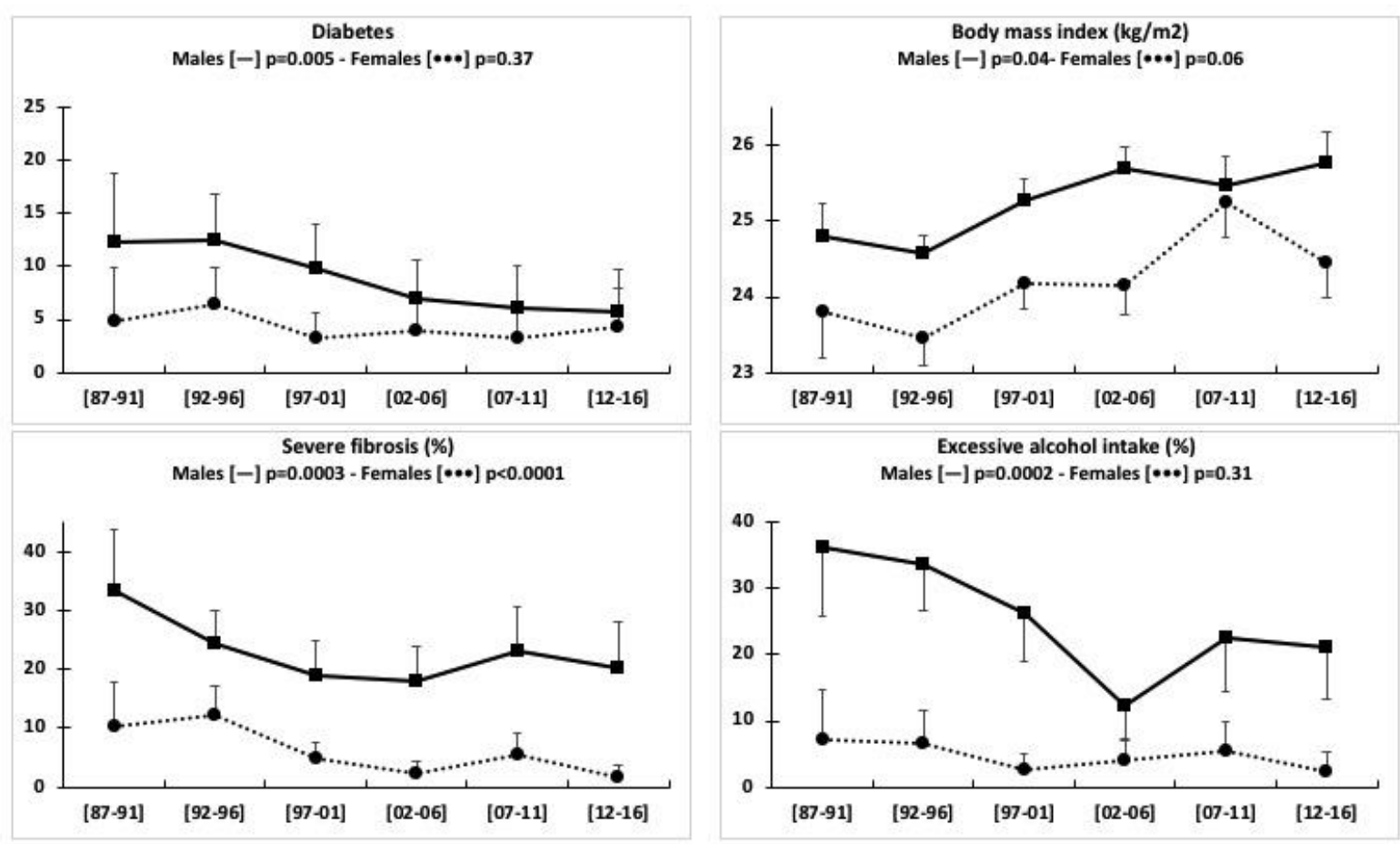


\section{Table 1}

\begin{tabular}{|c|c|c|c|c|}
\hline Years & {$[87-91] \quad[92-96]$} & [97-01] & {$[02-06]$} & [07-11] \\
\hline
\end{tabular}

Sex ratio (M/F)

$\begin{array}{rccccccc}\text { All } & 1.67 & 1.44 & 0.91 & 0.83 & 0.84 & 1.07 & 0.32 \\ \text { Probands } & 2.16 & 1.80 & 1.01 & 0.98 & 0.97 & 1.18 & 0.88 \\ \text { Relatives } & 0.74 & 0.92 & 0.70 & 0.60 & 0.58 & 0.72 & 0.08\end{array}$

Proband to relative ratio

$\begin{array}{rrrrrrrr}\text { All } & 3.48 & 2.13 & 2.76 & 1.84 & 2.54 & 3.88 & 0.39 \\ \text { Males } & 5.59 & 2.85 & 3.38 & 2.42 & 3.39 & 5.00 & 0.88 \\ \text { Females } & 1.91 & 1.46 & 2.33 & 1.49 & 2.04 & 3.07 & 0.08\end{array}$

* Test of Cochrane Armitage 


\begin{tabular}{|c|c|c|c|c|c|c|c|c|c|}
\hline wVariables & $\begin{array}{l}\text { iods } \\
\text { ients }\end{array}$ & $\begin{array}{l}{[87-91]} \\
\text { ean SD }\end{array}$ & 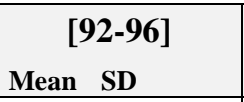 & $\begin{array}{l}\text { [97-01] } \\
\text { Iean SD }\end{array}$ & $\begin{array}{l}\text { [02-06] } \\
\text { Iean SD }\end{array}$ & $\begin{array}{r}\quad[07-11] \\
\text { Mean SD } \\
\end{array}$ & $\begin{array}{l}\quad[12-16] \\
\text { Mean SD }\end{array}$ & $\mathbf{p}^{*}$ & $\begin{array}{l}\text { All periods } \\
\text { Mean SD }\end{array}$ \\
\hline $\begin{array}{c}\text { Age } \\
(\text { years })\end{array}$ & $\begin{array}{c}\text { All } \\
\text { Males } \\
\text { Females } \\
n \text { tested }(M / F) \\
\end{array}$ & $\begin{array}{cc}45.2 & {[11.8]} \\
\mathbf{4 3 . 9} & {[11.5]} \\
\mathbf{4 7 . 3} & {[12.1]} \\
& 112 / 67 \\
\end{array}$ & $\begin{array}{rr}\mathbf{4 5 . 4} & {[12.8]} \\
\mathbf{4 5 . 1} & {[12.1]} \\
\mathbf{4 5 . 7} & {[13.8]} \\
& 262 / 182 \\
\end{array}$ & $\begin{array}{rr}\mathbf{4 4 . 6} & {[13.4]} \\
\mathbf{4 2 . 7} & {[12.5]} \\
\mathbf{4 6 . 3} & {[14.0]} \\
& 210 / 230 \\
\end{array}$ & $\begin{array}{rr}46.9 & {[13.4]} \\
45.8 & {[12.9]} \\
47.9 & {[13.8]} \\
& 202 / 244 \\
\end{array}$ & $\begin{array}{rr}\mathbf{4 7 . 1} & {[14.6]} \\
\mathbf{4 3 . 3} & {[12.5]} \\
\mathbf{5 0 . 4} & {[15.5]} \\
& 136 / 161 \\
\end{array}$ & $\begin{array}{rr}\mathbf{4 3 . 5} & {[13.9]} \\
\mathbf{4 3 . 2} & {[13.3]} \\
\mathbf{4 3 . 9} & {[14.6]} \\
& 126 / 118 \\
\end{array}$ & $\begin{array}{c}0.005 \\
0.1 \\
0.0035\end{array}$ & $\begin{array}{rc}45.6 & {[13.4]} \\
44.2 & {[12.5]} \\
47,0 & {[14.2]} \\
& 1048 / 1002 \\
\end{array}$ \\
\hline $\begin{array}{c}\text { Transferrin } \\
\text { saturation } \\
(\%)\end{array}$ & $\begin{array}{c}\text { All } \\
\text { Males } \\
\text { Females } \\
n \text { tested }(M / F) \\
\end{array}$ & $\begin{array}{ll}\mathbf{7 4 . 4} & {[17.6]} \\
\mathbf{7 6 . 8} & {[15.3]} \\
\mathbf{7 1 . 2} & {[19.9]} \\
& 75 / 57 \\
\end{array}$ & $\begin{array}{rr}\mathbf{7 4 . 2} & {[17.4]} \\
\mathbf{7 8 , 0} & {[15.7]} \\
\mathbf{6 8 . 9} & {[18.2]} \\
& 226 / 159 \\
\end{array}$ & $\begin{array}{rr}\mathbf{7 2 . 2} & {[22.1]} \\
\mathbf{7 9 , 0} & {[19.1]} \\
\mathbf{6 6 . 3} & {[22.8]} \\
& 170 / 200 \\
\end{array}$ & $\begin{array}{rr}\mathbf{7 1 . 9} & {[20.5]} \\
\mathbf{7 7 . 8} & {[18.8]} \\
\mathbf{6 7 . 2} & {[20.7]} \\
& 174 / 215 \\
\end{array}$ & $\begin{array}{rr}\mathbf{6 8 . 1} & {[19.1]} \\
\mathbf{7 4 . 9} & {[16.7]} \\
\mathbf{6 2 . 5} & {[19.1]} \\
& 120 / 147 \\
\end{array}$ & $\begin{array}{rr}66.1 & {[19.4]} \\
72.5 & {[19.6]} \\
59.5 & {[16.9]} \\
& 118 / 112 \\
\end{array}$ & $\begin{array}{c}<0.0001 \\
0.026 \\
0.0002\end{array}$ & $\begin{array}{rr}71.3 & {[19.8]} \\
76.9 & {[17.8]} \\
65.8 & {[20.2]} \\
& 883 / 885 \\
\end{array}$ \\
\hline$(\mu \mathrm{mg} / \mathrm{l})$ & $\begin{array}{c}\text { All } \\
\text { Males } \\
\text { Females } \\
n \text { tested }(M / F) \\
\end{array}$ & $\begin{array}{cc}\mathbf{1 7 5 5} & {[1891]} \\
\mathbf{2 2 4 2} & {[2068]} \\
\mathbf{9 7 1} & {[1221]} \\
& 98 / 61 \\
\end{array}$ & $\begin{array}{cc}\mathbf{1 4 9 6} & {[1601]} \\
\mathbf{1 8 6 5} & {[1582]} \\
\mathbf{9 7 4} & {[1483]} \\
& 242 / 171 \\
\end{array}$ & $\begin{array}{cc}\mathbf{1 0 2 9} & {[1295]} \\
\mathbf{1 5 4 0} & {[1530]} \\
\mathbf{5 5 3} & {[772]} \\
& 186 / 200 \\
\end{array}$ & $\begin{array}{cl}\mathbf{9 1 4} & {[1573]} \\
\mathbf{1 4 9 2} & {[2065]} \\
\mathbf{4 1 4} & {[632]} \\
& 187 / 216 \\
\end{array}$ & $\begin{array}{cc}\mathbf{1 0 3 3} & {[1154]} \\
\mathbf{1 4 1 7} & {[1086]} \\
\mathbf{6 9 8} & {[1110]} \\
& 129 / 148 \\
\end{array}$ & $\begin{array}{cc}\mathbf{9 0 9} & {[941]} \\
\mathbf{1 3 4 5} & {[1072]} \\
\mathbf{4 4 3} & {[434]} \\
& 123 / 115 \\
\end{array}$ & $\begin{array}{l}<0.0001 \\
<0.0001 \\
<0.0001\end{array}$ & $\begin{array}{cc}1154 & {[1459]} \\
1642 & {[1644]} \\
637 & {[1002]} \\
& 965 / 911 \\
\end{array}$ \\
\hline $\begin{array}{r}\text { Iron } \\
\text { removed }\end{array}$ & $\begin{array}{c}\text { All } \\
\text { Males } \\
\text { Females } \\
n \text { tested }(M / F) \\
\end{array}$ & $\begin{array}{cr}\mathbf{7 . 7} & {[5.9]} \\
\mathbf{9 . 7} & {[6.3]} \\
\mathbf{4 . 7} & {[3.5]} \\
& 64 / 42 \\
\end{array}$ & $\begin{array}{rr}\mathbf{8 . 1} & {[7.3]} \\
\mathbf{9 . 6} & {[7.6]} \\
\mathbf{5 . 7} & {[6.1]} \\
& 145 / 93 \\
\end{array}$ & $\begin{array}{cc}\mathbf{5 . 2} & {[5.5]} \\
\mathbf{7 . 6} & {[6.4]} \\
\mathbf{2 . 9} & {[2.9]} \\
& 125 / 128 \\
\end{array}$ & $\begin{array}{cc}4.9 & {[4.8]} \\
7.4 & {[5.6]} \\
2.6 & {[2.1]} \\
& 142 / 151 \\
\end{array}$ & $\begin{array}{lr}\mathbf{4 . 5} & {[4.2]} \\
\mathbf{6 . 6} & {[5.0]} \\
\mathbf{2 . 9} & {[2.5]} \\
& 76 / 94 \\
\end{array}$ & $\begin{array}{lr}\mathbf{3 . 6} & {[3.0]} \\
\mathbf{5 , 0} & {[3.3]} \\
\mathbf{2 , 0} & {[1.6]} \\
& 60 / 56 \\
\end{array}$ & $\begin{array}{l}<0.0001 \\
<0.0001 \\
<0.0001\end{array}$ & $\begin{array}{cc}5.7 & {[5.7]} \\
7.9 & {[6.3]} \\
3.3 & {[3.6]} \\
& 612 / 564 \\
\end{array}$ \\
\hline $\begin{array}{c}\text { BMI } \\
(\mathrm{Kg} / \mathrm{m} 2)\end{array}$ & $\begin{array}{c}\text { All } \\
\text { Males } \\
\text { Females } \\
n \text { tested }(M / F) \\
\end{array}$ & $\begin{array}{rr}\mathbf{2 4 . 4} & {[3.7]} \\
\mathbf{2 4 . 8} & {[3.7]} \\
\mathbf{2 3 . 8} & {[3.7]} \\
& 72 / 39 \\
\end{array}$ & $\begin{array}{rc}\mathbf{2 4 . 1} & {[3.6]} \\
\mathbf{2 4 . 6} & {[3.2]} \\
\mathbf{2 3 . 4} & {[4.1]} \\
& 188 / 129 \\
\end{array}$ & $\begin{array}{cc}\mathbf{2 4 . 7} & {[4.1]} \\
\mathbf{2 5 . 3} & {[3.5]} \\
\mathbf{2 4 . 2} & {[4.5]} \\
& 155 / 171 \\
\end{array}$ & $\begin{array}{rc}\mathbf{2 4 . 9} & {[4.4]} \\
\mathbf{2 5 . 7} & {[3.5]} \\
\mathbf{2 4 . 1} & {[4.9]} \\
& 149 / 175 \\
\end{array}$ & $\begin{array}{cc}\mathbf{2 5 . 4} & {[4.9]} \\
\mathbf{2 5 . 5} & {[4.2]} \\
\mathbf{2 5 . 3} & {[5.5]} \\
& 117 / 135 \\
\end{array}$ & $\begin{array}{cc}25.1 & {[4.6]} \\
25.8 & {[4.4]} \\
24.4 & {[4.7]} \\
& 114 / 107 \\
\end{array}$ & $\begin{array}{l}0.01 \\
0.04 \\
0.06\end{array}$ & $\begin{array}{rc}24.8 & {[4.3]} \\
25.2 & {[3.7]} \\
24.3 & {[4.7]} \\
& 795 / 756 \\
\end{array}$ \\
\hline Variables & & \begin{tabular}{c}
\multicolumn{2}{c}{$[87-91]$} \\
$\% \quad[95 \% \mathrm{CI}]$ \\
\end{tabular} & $\begin{array}{cc} & {[92-96]} \\
\% \quad[95 \% \mathrm{CI}] \\
\end{array}$ & $\begin{array}{c} \\
\quad[97-01] \\
\% \quad[95 \% \mathrm{CI}] \\
\end{array}$ & \begin{tabular}{c}
\multicolumn{2}{c}{$[02-06]$} \\
$\% \quad[95 \% \mathrm{CI}]$ \\
\end{tabular} & 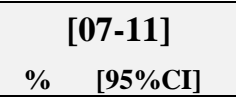 & 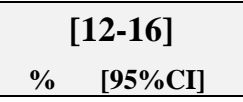 & $\mathbf{p}^{* *}$ & $\begin{array}{l}\text { All periods } \\
\% \quad[95 \% \mathrm{CI}] \\
\end{array}$ \\
\hline Diab & $\begin{array}{c}\text { All } \\
\text { Males } \\
\text { Females } \\
n \text { tested }(M / F) \\
\end{array}$ & $\begin{array}{cl}\mathbf{9 . 4} & {[4.9-13.9]} \\
\mathbf{1 2 . 2} & {[5.7-18.7]} \\
\mathbf{4 . 8} & {[0.0-10.1]} \\
& 98 / 62 \\
\end{array}$ & $\begin{array}{cc}\mathbf{9 . 8} & {[6.9-12.7]} \\
\mathbf{1 2 . 5} & {[8.2-16.8]} \\
\mathbf{6 . 4} & {[2.8-10.0]} \\
& 224 / 173\end{array}$ & $\begin{array}{cc}\mathbf{6 . 4} & {[4.0-8.8]} \\
\mathbf{9 . 8} & {[5.6-14.0]} \\
\mathbf{3 . 3} & {[0.9-5.7]} \\
& 193 / 213 \\
\end{array}$ & $\begin{array}{cc}\mathbf{5 . 3} & {[3.1-7.5]} \\
\mathbf{7 , 0} & {[3.3-10.7]} \\
\mathbf{4 , 0} & {[1.5-6.5]} \\
& 187 / 228 \\
\end{array}$ & $\begin{array}{cc}\mathbf{4 . 6} & {[2.2-7.0]} \\
\mathbf{6 , 0} & {[2.0-10.0]} \\
\mathbf{3 . 3} & {[0.5-6.1]} \\
& 133 / 153 \\
\end{array}$ & $\begin{array}{cc}\mathbf{5 , 0} & {[2.2-7.8]} \\
\mathbf{5 . 7} & {[1.6-9.8]} \\
\mathbf{4 . 2} & {[0.6-7.8]} \\
& 123 / 118 \\
\end{array}$ & $\begin{array}{c}0.002 \\
0.005 \\
0.37\end{array}$ & $\begin{array}{cc}6.7 & {[5.6-7.8]} \\
9.1 & {[7.3-10.9]} \\
4.2 & {[2.9-5.5]} \\
& 958 / 947 \\
\end{array}$ \\
\hline $\begin{array}{l}\text { Severe } \\
\text { fibrosis } \\
(\%)\end{array}$ & $\begin{array}{c}\text { All } \\
\text { Males } \\
\text { Females } \\
n \text { tested }(M / F) \\
\end{array}$ & $\begin{array}{cc}\mathbf{3 3 . 6} & {[26.1-41.1]} \\
\mathbf{4 7 . 8} & {[37.6-58.0]} \\
\mathbf{1 1 . 7} & {[3.6-19.8]} \\
& 92 / 60 \\
\end{array}$ & $\begin{array}{cc}\mathbf{2 2 . 9} & {[18.8-27.0]} \\
\mathbf{2 9 . 3} & {[23.4-35.2]} \\
\mathbf{1 4 . 2} & {[8.9-19.5]} \\
232 / 169 \\
\end{array}$ & $\begin{array}{cl}\mathbf{1 4 . 6} & {[11.0-18.2]} \\
\mathbf{2 4 . 4} & {[18.1-30.7]} \\
\mathbf{5 . 7} & {[2.4-9.0]} \\
& 176 / 193 \\
\end{array}$ & $\begin{array}{cl}\mathbf{1 1 , 0} & {[7.9-14.1]} \\
\mathbf{2 1 . 3} & {[15.1-27.5]} \\
\mathbf{2 . 8} & {[0.6-5.0]} \\
& 169 / 212 \\
\end{array}$ & $\begin{array}{cc}\mathbf{1 4 . 5} & {[10.2-18.8]} \\
\mathbf{2 5 . 6} & {[17.7-33.5]} \\
\mathbf{5 . 5} & {[1.8-9.2]} \\
& 117 / 145 \\
\end{array}$ & $\begin{array}{cl}\mathbf{1 1 . 6} & {[7.4-15.8]} \\
\mathbf{2 1 . 8} & {[14.1-29.5]} \\
\mathbf{1 . 8} & {[0.0-4.2]} \\
& 110 / 114 \\
\end{array}$ & $\begin{array}{c}<0.0001 \\
0.0003 \\
<0.0001\end{array}$ & $\begin{array}{cc}16.9 & {[15.2-18.6]} \\
27.3 & {[24.4-30.2]} \\
6.5 & {[4.9-8.1]} \\
& 896 / 893 \\
\end{array}$ \\
\hline $\begin{array}{c}\text { Excessive } \\
\text { alcohol } \\
\text { intake }(\%)\end{array}$ & $\begin{array}{c}\text { All } \\
\text { Males } \\
\text { Females } \\
n \text { tested }(M / F) \\
\end{array}$ & $\begin{array}{cc}\mathbf{2 6 . 2} & {[18.4-34.0]} \\
\mathbf{3 6 . 3} & {[25.8-46.8]} \\
\mathbf{7 . 1} & {[0.0-14.9]} \\
& 80 / 42 \\
\end{array}$ & $\begin{array}{cc}\mathbf{2 3 . 7} & {[18.7-28.7]} \\
\mathbf{3 3 . 7} & {[26.8-40.6]} \\
\mathbf{6 . 7} & {[1.9-11.5]} \\
& 178 / 105 \\
\end{array}$ & $\begin{array}{cl}\mathbf{1 4 , 0} & {[10.1-17.9]} \\
\mathbf{2 6 . 2} & {[19.1-33.3]} \\
\mathbf{2 . 5} & {[0.1-4.9]} \\
& 149 / 158 \\
\end{array}$ & $\begin{array}{cc}\mathbf{8 , 0} & {[5.0-11.0]} \\
\mathbf{1 2 . 4} & {[7.2-17.6]} \\
\mathbf{4 . 1} & {[1.1-7.1]} \\
& 153 / 171 \\
\end{array}$ & $\begin{array}{cc}\mathbf{1 3 . 9} & {[9.3-18.5]} \\
\mathbf{2 2 . 4} & {[14.5-30.3]} \\
\mathbf{5 . 5} & {[1.2-9.8]} \\
& 107 / 109\end{array}$ & $\begin{array}{cl}\mathbf{1 2 . 8} & {[8.0-17.6]} \\
\mathbf{2 1 . 2} & {[13.3-29.1]} \\
\mathbf{2 . 4} & {[0.0-5.7]} \\
& 104 / 84 \\
\end{array}$ & $\begin{array}{c}<0.0001 \\
0.0002 \\
0.31\end{array}$ & $\begin{array}{cl}15.4 & {[13.5-17.3]} \\
25,0 & {[21.9-28.1]} \\
4.3 & {[2.8-5.8]} \\
& 771 / 669 \\
\end{array}$ \\
\hline $\begin{array}{c}\text { Tobacco } \\
\text { smoking }(\%)\end{array}$ & $\begin{array}{c}\text { All } \\
\text { Males } \\
\text { Females } \\
n \text { tested }(M / F) \\
\end{array}$ & $\begin{array}{cl}\mathbf{2 8 . 1} & {[19.1-37.1]} \\
\mathbf{2 8 , 0} & {[17.8-38.2]} \\
\mathbf{2 8 . 6} & {[9.3-47.9]} \\
& 75 / 21 \\
\end{array}$ & $\begin{array}{cc}\mathbf{2 9 . 8} & {[23.6-36.0]} \\
\mathbf{2 9 . 5} & {[21.9-37.1]} \\
\mathbf{3 0 . 4} & {[19.5-41.3]} \\
& 139 / 69 \\
\end{array}$ & $\begin{array}{ll}\mathbf{3 1 . 6} & {[25.9-37.3]} \\
\mathbf{4 0 . 4} & {[32.3-48.5]} \\
\mathbf{2 0 . 5} & {[13.0-28.0]} \\
& 141 / 112 \\
\end{array}$ & $\begin{array}{cc}\mathbf{2 8 . 8} & {[23.6-34.0]} \\
\mathbf{3 4 , 0} & {[26.3-41.7]} \\
\mathbf{2 3 . 7} & {[16.8-30.6]} \\
& 147 / 148 \\
\end{array}$ & $\begin{array}{cc}\mathbf{3 0 . 7} & {[24.7-36.7]} \\
\mathbf{3 2 . 4} & {[23.6-41.2]} \\
\mathbf{2 9 . 2} & {[21.1-37.3]} \\
& 108 / 120 \\
\end{array}$ & $\begin{array}{cc}\mathbf{3 1 . 5} & {[25.1-37.9]} \\
\mathbf{3 7 . 6} & {[28.5-46.7]} \\
\mathbf{2 4 . 2} & {[15.4-33.0]} \\
& 109 / 91 \\
\end{array}$ & $\begin{array}{l}0.67 \\
0.24 \\
0.93\end{array}$ & $\begin{array}{cc}30.2 & {[27.7-32.7]} \\
34.1 & {[30.6-37.6]} \\
25.3 & {[21.7-28.9]} \\
& 719 / 561 \\
\end{array}$ \\
\hline
\end{tabular}

* ANOVA with Levene correction - ** Test of Cochrane Armitage - 


\begin{tabular}{|c|c|c|c|c|c|c|c|c|}
\hline \multirow[b]{3}{*}{ Year of diagnosis } & \multicolumn{2}{|c|}{ Transferrin saturation } & \multicolumn{2}{|c|}{ Serum ferritin } & \multicolumn{2}{|c|}{ Amount of iron removed } & \multicolumn{2}{|c|}{ Severe iron burden } \\
\hline & Males & Females & Males & Females & Males & Females & Males & Females \\
\hline & & & & & & & & \\
\hline [87-91] & $1.59[0.94-2.70]$ & $3.43[1.87-6.32]$ & $1.77[1.04-3.00]$ & $2.58[1.40-4.74]$ & $4.11[2.27-7.43]$ & $4.00[1.97-8.12]$ & $2.47[1.30-4.68]$ & $4.69[2.31-9.51]$ \\
\hline [92-96] & $1.66[1.09-2.52]$ & $2.66[1.68-4.22]$ & $1.56[1.01-2.40]$ & $1.99[1.26-3.16]$ & $2.83[1.74-4.60]$ & $2.98[1.69-5.25]$ & $2.51[1.53-4.13]$ & $4.12[2.33-7.27]$ \\
\hline [97-01] & 1.85 [1.18-2.89] & $2.14[1.38-3.32]$ & $1.14[0.73-1.77]$ & $1.01[0.65-1.56]$ & $1.84[1.10-3.09]$ & $1.77[1.06-2.96]$ & $1.78[1.07-2.95]$ & $3.40[1.95-5.91]$ \\
\hline [02-06] & $1.55[1.00-2.40]$ & $2.31[1.50-3.57]$ & $0.89[0.57-1.38]$ & $0.75[0.48-1.16]$ & $1.51[0.92-2.46]$ & $1.44[0.87-2.37]$ & $1.43[0.87-2.35]$ & $3.28[1.89-5.68]$ \\
\hline [07-11] & $0.96[0.60-1.56]$ & $1.50[0.95-2.38]$ & $1.06[0.66-1.71]$ & $1.18[0.74-1.90]$ & $1.57[0.91-2.73]$ & $1.55[0.90-2.67]$ & $1.08[0.63-1.83]$ & $1.58[0.87-2.87]$ \\
\hline [12-16] & 1 & 1 & 1 & 1 & 1 & 1 & 1 & 1 \\
\hline \multicolumn{9}{|l|}{ Age at diagnosis } \\
\hline $18-34$ & 1 & $0.67[0.47-0.95]$ & 1 & $0.32[0.22-0.45]$ & 1 & $0.47[0.32-0.69]$ & 1 & \\
\hline $35-49$ & $1.49[1.09-2.03]$ & $0.69[0.52-0.92]$ & $2.88[2.09-3.97]$ & $0.32[0.24-0.43]$ & $2.28[1.62-3.22]$ & $0.66[0.47-0.93]$ & $1.69[1.18-2.42]$ & \\
\hline$\geq 50$ & $1.44[1.02-2.03]$ & 1 & $3.52[2.44-5.07]$ & 1 & $2.95[2.00-4.36]$ & 1 & $1.87[1.26-2.78]$ & \\
\hline \multicolumn{9}{|l|}{ Proband status } \\
\hline No & 1 & 1 & 1 & 1 & 1 & 1 & 1 & 1 \\
\hline Yes & $1.48[1.10-2.00]$ & $1.61[1.24-2.09]$ & 2.14 [1.57-2.93] & $2.98[2.26-3.92]$ & $1.72[1.21-2.47]$ & 1.56 [1.13-2.15] & $1.74[1.23-2.45]$ & $1.63[1.21-2.21]$ \\
\hline \multicolumn{9}{|c|}{ Tobacco smoking } \\
\hline No & 1 & 1 & & & & & 1 & 1 \\
\hline Yes & $1.49[1.11-2.00]$ & $1.79[1.23-2.62]$ & & & & & $1.65[1.14-2.40]$ & $1.67[1.11-2.51]$ \\
\hline \multicolumn{9}{|l|}{ Body mass index } \\
\hline$<25$ & & 1 & 1 & & & & & \\
\hline $25-30$ & & $0.80[0.58-1.09]$ & $1.12[0.84-1.48]$ & & & & & \\
\hline$\geq 30$ & - & $0.61[0.38-0.96]$ & $1.61[1.00-2.60]$ & & & & & \\
\hline \multicolumn{9}{|c|}{ Excessive alcohol intake } \\
\hline No & & 1 & 1 & 1 & 1 & & & 1 \\
\hline Yes & & $2.86[1.13-7.27]$ & $1.51[1.08-2.12]$ & $1.98[1.20-3.27]$ & $1.45[1.00-2.10]$ & & & $3.12[1.20-8.11]$ \\
\hline \multicolumn{9}{|l|}{ Diabetes } \\
\hline No & & & 1 & & 1 & 1 & & \\
\hline Yes & & & $2.51[1.70-3.71]$ & & $2.23[1.50-3.32]$ & $1.64[1.04-2.59]$ & & \\
\hline
\end{tabular}


Graphical abstract
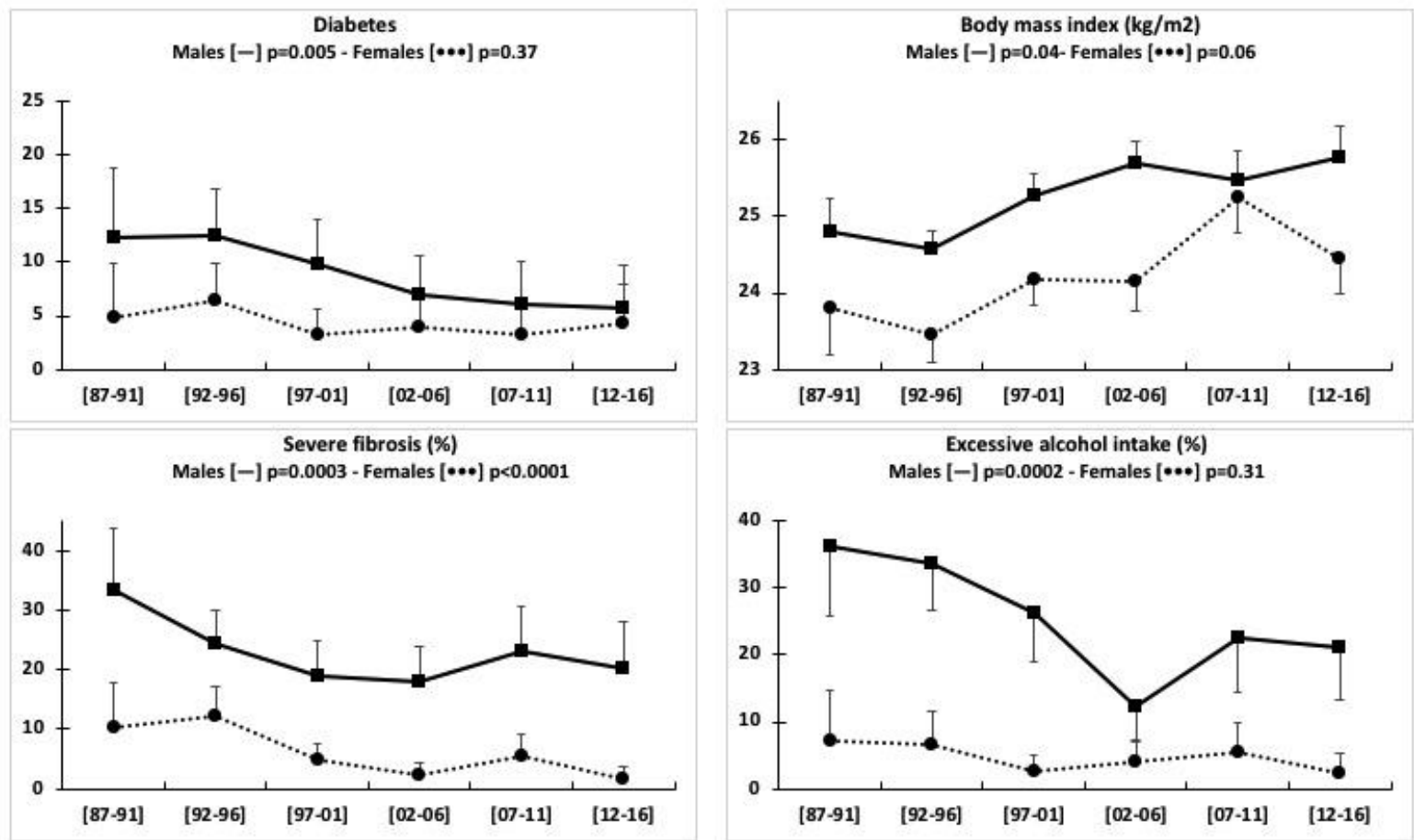


\section{Highlights}

- HFE hemochromatosis has became less and less severe over the last 30 years despite older age at diagnosis

- Chronic fatigue and distal arthralgias remain the most frequent opening symptoms

- Reduction of alcohol consumption and increased frequency of overweight resulting in increased hepcidin production may explain the changing face of the disease

- Tobacco smoking may aggravate iron loading 